\title{
Characterization and production of slip casts mullite-zirconia composites
}

\author{
H. Aydin ${ }^{1}$ (D) . G. Tokatas ${ }^{1}$
}

C Springer Nature Switzerland AG 2018

\begin{abstract}
In this study, mullite-zirconia composites were prepared by reaction sintering of alumina, kaolinite zircon and colemanite powder. Slip casting method was also employed for production of these composites. Two different compositions were prepared with and without colemanite additive. The main purpose of this work was to determine the optimum conditions for mullite-zirconia synthesis in addition to the effects of starting composition, solid concentration of aqueous suspensions and sintering temperature. The resulting sintered materials were characterized in terms of bulk and relative density, firing shrinkage, XRD and SEM. XRD peaks suggested fully developed mullite and zirconia phases by reaction sintering of zircon, kaolinite, alumina and colemanite phases. Zircon usually dissociates at a temperature higher than $1650^{\circ} \mathrm{C}$. However, it has been shown in this study that zircon dissociates at about $1450^{\circ} \mathrm{C}$ due to the presence of colemanite. The results of the study indicate that $90 \%$ of relative density was achieved as the solid concentration is increased up to $55 \%$ in case for slip-casted specimens with colemanite additive (MZC55 with $55 \%$ solid concentration). The microstructure of all composites is composed of irregularly shaped mullite grains and round-shaped zirconia grains which are distributed intragranularly and intergranularly.
\end{abstract}

Keywords Mullite-zirconia composites $\cdot$ Slip casting $\cdot$ Reaction sintering $\cdot$ Physical properties

\section{Introduction}

The system of $\mathrm{Al}_{2} \mathrm{O}_{3}-\mathrm{SiO}_{2}$ is one of the most important binary systems in ceramics, and mullite is the only intermediate compound in this thermodynamically stable system. Mullite has recently become one of the important materials in electronic, optical and high temperature structural applications due to its attractive properties such as excellent high temperature strength, resistance to creep and thermal shock, low dielectric and thermal expansion constants [1, 2]. Although mullite is among the traditional refractory materials, it has started to gain importance in recent years as a candidate material for advanced ceramics applications [3]. However, mullite has moderate rupture strength and fracture toughness at room temperature.
Zirconia is used as an additive in order to improve these properties [4].

Zirconia has different and superior properties in comparison with other oxide ceramics. It is a high-technology ceramic with a high melting temperature of $2680^{\circ} \mathrm{C}$, high abrasion resistance, low refractive index, low thermal conductivity, high electrical resistance and ionic conductivity at high temperature. It can be observed upon examining the mechanical properties of zirconia that it has high chemical and dimensional stability, mechanical strength and toughness [5, 6]. In addition, zirconia is also widely used as a heater element and insulating material, in production of abrasive cutting tools, extrusion molds, abrasion-resistant machine parts, ceramic coatings against oxidation and in the manufacturing of thermal barriers,

H. Aydin, hediye.aydin@dpu.edu.tr | 1 Department of Metallurgy and Material Engineering, Kütahya Dumlupınar University, 43100 Kutahya, Turkey.

SN Applied Sciences (2019) 1:56 | https://doi.org/10.1007/s42452-018-0061-4 
fuel cells [7], piezoelectric, electro-optical circuits and capacitors, solid electrolyte and oxygen sensors [8].

The comprehensive use of mullite-zirconia composites is due to the fact that zirconia dispersion in mullite matrix improves the thermo-mechanical properties, leading to toughness by transformation and micro-cracking [9-11]. Mullite-zirconia composites have special importance in technological applications due to their good properties such as toughness, chemical stability and high-creep resistance. In practice, they are employed in furnaces (blast furnaces, etc.) used for dissolving and application of metals, as refractory bricks in glass melting and ceramic sintering kilns, in waste incineration plants, in kilns for annealing and hardening as well as in cement industry [11-14].

Various production methods, such as solid state sintering, thermal plasma fusion, sol-gel, spark plasma sintering, laser floating zone directional solidification method, are adopted for the synthesis of mullite-zirconia composites [15-20]. Generally, slip casting is exploited to yield zirconia-toughened mullite by improving the density and microstructure of the body so that this technique is applied in the fabrication process of many composites and refractories [10]. Besides, slip casting is used as a conventional method in order to provide good mechanical properties and to obtain fine and homogeneous microstructures free of agglomerates and packing variations in green composites [12, 21, 22].

In this study, density and phase analyses and microstructural characterization were carried out for dense composite materials obtained via slip casting method from two different mixtures prepared (non-additive and containing colemanite). The effects of different additives on the physical, microstructure, thermo-mechanical properties and sintering behavior of mullite-zirconia composites have been studied by several researchers. It has been observed that additives which do not form a solid solution with the matrix such as $\mathrm{CaO}$ and $\mathrm{MgO}$ encourage the sintering rate by way of a transitory liquid formation [10, 13]. Pena et al. [23] studied the impact of $\mathrm{MgO}$ on mullite-zirconia composites and determined that the addition of a small amount of magnesia increased the rate of densification by forming a small amount of liquid phase. Similarly, titanium decreased the sintering temperature of this composite by forming a small amount of transient liquid phase [10]. $\mathrm{CeO}_{2}$ additive enhanced the mullitization rate [24]. In our work, colemanite provided the dissociation of zircon at a lower temperature as well as the formation of mullite and zirconia. As was the case in our previous study [25], it has also been possible in this study to use colemanite in mixtures favoring the reaction between alumina, zircon and kaolinite. Main differences between our previous study and this study can be explained as follows:
Same mixtures were used in the previous study [25]; however, these mixtures were uniaxial pressed. Therefore, density values of uniaxial pressed mixtures were higher in comparison with those formed by slip casting. Depending on the forming technique, green density of materials after formed via slip casting was lower than by uniaxial pressed at the same sintering temperature [26]. Thus, the relative density values of materials in this study after sintering are lower than those of the previous study [25]. Moreover, it has also been possible to favor the reaction between alumina, zircon and kaolinite using colemanite in both mixtures.

The purpose of this study was to study the impact of colemanite, solid concentration of aqueous suspensions and sintering temperature on density, mineralogical and microstructural properties of slip casts mullite-zirconia composites.

\section{Experimental}

Starting powders were traditionally available zircon ( $\mathrm{ZrSiO}_{4}$, Johnsen Matthey, Sereltaş, Istanbul), kaolinite $\left(\mathrm{Al}_{2} \mathrm{Si}_{2} \mathrm{O}_{5}(\mathrm{OH})_{4}\right.$, Kütahya Porselen, Kütahya), commercially available alumina $\left(\mathrm{Al}_{2} \mathrm{O}_{3}, \mathrm{BDH}\right.$ Limited Poole, Germany) and colemanite $\left(\mathrm{Ca}_{2} \mathrm{~B}_{6} \mathrm{O}_{11} 5 \mathrm{H}_{2} \mathrm{O}\right.$, Eti Mining Company, Turkey). The chemical compositions of the raw materials used in this study were analyzed via X-ray fluorescence for which the results are presented in Table 1.

$A \mathrm{Ca}_{2} \mathrm{~B}_{6} \mathrm{O}_{11} 5\left(\mathrm{H}_{2} \mathrm{O}\right)$ addition at a range of $7 \mathrm{wt} \%$ range was used for studying the impact of colemanite addition on the properties of these composites. The weight ratio of colemanite during the preparation of the mixtures was calculated by considering the amount of $\mathrm{CaO}(\sim 14 \mathrm{~mol} \%)$ required for the zirconia to be partly stable.

On the brink of MZO (additive-free mixture) and MZC (mixture containing colemanite), two different mixtures were prepared. Two mixtures, MZO-MZC, are calculated according to Table 2 . The prepared mixtures were ballmilled on a planetary mill (Retsch PM 200) for $6 \mathrm{~h}$ using $\mathrm{ZrO}_{2}$ balls as grinding media in methyl alcohol as a medium.

The obtained average grain sizes are given in Table 3 for the prepared compositions as a result of $6-\mathrm{h}$ milling process using Malvern Instrument, Mastersizer 2000 ver. 3.01.

Aqueous suspensions at $\mathrm{pH} \sim 9.02$ containing $45-50-55 \%$ solids by weight were prepared in order to form the prepared mixtures via slip casting using Darvan C [PMMA (polymethylmethacrylate)] as a dispersant at a rate of $\sim 0.25 \%$ by weight. The prepared concentrated suspensions were consolidated into a plaster mold to produce pellets of $20 \mathrm{~mm}$ diameter which were dried using 
Table 1 Chemical composition of starting raw materials (wt\%)

\begin{tabular}{|c|c|c|c|c|}
\hline Constituents & $\begin{array}{l}\text { Zircon } \\
\left(\mathrm{ZrSiO}_{4}\right)\end{array}$ & $\begin{array}{l}\text { Kaolinite } \\
\left(\mathrm{Al}_{2} \mathrm{O}_{3} \cdot 2 \mathrm{SiO}_{2} \cdot 2 \mathrm{H}_{2} \mathrm{O}\right)\end{array}$ & $\begin{array}{l}\text { Alumina } \\
\left(\mathrm{Al}_{2} \mathrm{O}_{3}\right)\end{array}$ & $\begin{array}{l}\text { Colemanite } \\
\left(\mathrm{Ca}_{2} \mathrm{~B}_{6} \mathrm{O}_{11} 5\left(\mathrm{H}_{2} \mathrm{O}\right)\right.\end{array}$ \\
\hline $\mathrm{SiO}_{2}$ & 29.96 & 53.70 & 0.02 & 5.54 \\
\hline $\mathrm{ZrO}_{2}$ & 64.08 & - & - & - \\
\hline $\mathrm{Al}_{2} \mathrm{O}_{3}$ & 0.02 & 31.94 & 97.75 & 0.10 \\
\hline $\mathrm{CaO}$ & 0.11 & 0.11 & 0.40 & 28.96 \\
\hline $\mathrm{B}_{2} \mathrm{O}_{3}$ & - & - & - & 35.69 \\
\hline $\mathrm{MgO}$ & 0.03 & 0.04 & 0.02 & 1.80 \\
\hline $\mathrm{Fe}_{2} \mathrm{O}_{3}$ & 0.07 & 1.18 & 0.04 & 0.05 \\
\hline $\mathrm{K}_{2} \mathrm{O}$ & 0.04 & 0.14 & 0.01 & 0.02 \\
\hline $\mathrm{Na}_{2} \mathrm{O}$ & 0.11 & 0.10 & 0.04 & 0.05 \\
\hline $\mathrm{TiO}_{2}$ & 0.22 & 0.30 & 0.01 & - \\
\hline $\mathrm{MnO}$ & - & - & - & 0.01 \\
\hline $\mathrm{SrO}$ & 0.07 & - & - & 0.85 \\
\hline $\mathrm{HfO}_{2}$ & 1.10 & - & - & - \\
\hline $\mathrm{P}_{2} \mathrm{O}_{5}$ & 1.15 & - & - & - \\
\hline Loss of temperature & 1.18 & 12.57 & 1.52 & 24.77 \\
\hline
\end{tabular}

Table 2 Mixture compositions with codes

\begin{tabular}{lllll}
\hline & \multicolumn{4}{l}{ Compositions (wt\%) } \\
\cline { 2 - 5 } & Zircon & Alumina & Kaolinite & Colemanite \\
\hline MZO & 30 & 45 & 25 & - \\
MZC & 40 & 43 & 10 & 7 \\
\hline
\end{tabular}

Table 3 Physical properties of the compositions used in the study

\begin{tabular}{lcc}
\hline Physical properties & MZ0 & MZC \\
\hline Particle size & & \\
$d_{(0,1)} \mu \mathrm{m}$ & 0.104 & 0.558 \\
$d_{(0,5)} \mu \mathrm{m}$ & 1.758 & 1.956 \\
$d_{(0,9)} \mu \mathrm{m}$ & 22.574 & 23.01 \\
Surface area & & \\
BET, $\mathrm{m}^{2} / \mathrm{g}$ & 4.3 & 4.1 \\
\hline
\end{tabular}

an oven at a constant temperature of $100^{\circ} \mathrm{C}$ after one day of natural drying.

Pellets (MZ045, MZ050, MZ055, MZC45, MZC50 and MZC55) were prepared from aqueous suspensions containing $45-50-55 \%$ solids by weight to synthesize the mullite-zirconia composite material by reaction sintering and to identify the physical properties in the synthesized material sintered at $1450-1550^{\circ} \mathrm{C}$. The sintering temperature was increased by $5^{\circ} \mathrm{C}$ per minute after which it was kept constant for a period of $5 \mathrm{~h}$ and was similarly allowed to cool down at $5^{\circ} \mathrm{C} / \mathrm{min}$. Crystalline phases present in sintered bodies were determined via X-ray diffraction (PANalytical, an empyrean brand model, $\mathrm{Cu} \mathrm{K}_{\mathrm{a}}$ radiation and $\mathrm{Ni}$ filter at $10-50^{\circ}$ ). The microstructures of sintered composites were studied via scanning electron microscopy (FEI Nova NanoSEM 650) on the surfaces.

\section{Results and Discussion}

\subsection{XRD analyses}

\subsubsection{XRD Analyses of the MZ045 composition}

The results obtained following XRD analyses of the MZ045 mixture specimens sintered at 1450,1500 and $1550^{\circ} \mathrm{C}$ can be seen in Fig. 1. As can be seen from the XRD pattern of the MZ045 mixture (Fig. 1), the specimens were sintered at $1450^{\circ} \mathrm{C}$ with the sintered specimens consisting of zircon, corundum, quartz, monoclinic zirconia and mullite phases. Alumina, silica and a significant amount of zircon can be observed at $1450^{\circ} \mathrm{C}$ following the decomposition.

The decomposition of zircon, which had probably begun earlier, continued at $1450^{\circ} \mathrm{C}$; however, it was still not completed at $1550^{\circ} \mathrm{C}$. It is thought that this causes the reactions not to be completed especially during sintering at $1450{ }^{\circ} \mathrm{C}$ since packing and intergranular interactions between grains in a composition containing $45 \%$ solids by weight are low. One possible mechanism is segregation of particles of different sizes, which is increased when solid loading is low and, thus, hindered settling is reduced $[27,28]$. Another reason for this situation is the lack of any additive in the prepared mixture. Zircon is the only compound in the $\mathrm{ZrO}_{2}-\mathrm{SiO}_{2}$ two-component phase system. It decomposes into $\mathrm{ZrO}_{2}$ and $\mathrm{SiO}_{2}$ before melting. Impurities not only reduce the decomposition temperature of zircon, but also decrease the viscosity 
Fig. 1 XRD patterns of MZ045 composition specimens sintered at 1450, 1500 and $1550^{\circ} \mathrm{C}$. M: mullite, $\mathrm{B}: \mathrm{m}-\mathrm{ZrO}_{2}$ $\mathrm{Z}: \mathrm{t}-\mathrm{ZrO}_{2}, \mathrm{Z}: \mathrm{ZrSiO}_{4}, \mathrm{C}:$ corundum, $Q:$ quartz

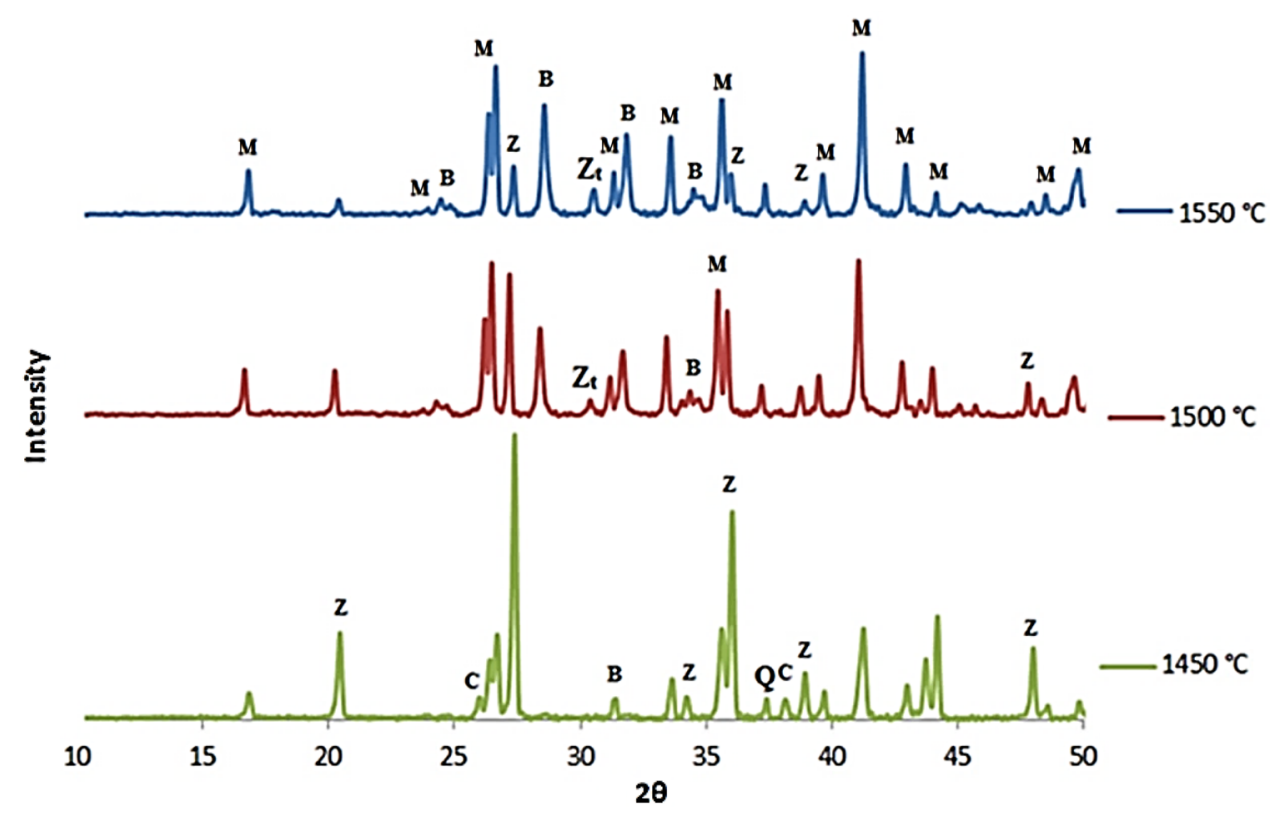

of the formed amorphous phase (silica glass) as well. It is known that silica fluids with a high basicity ratio are higher in fluids. Therefore, alkalis (basic oxides) from additives such as colemanite may decrease the viscosity of silica (high content) liquids [22, 25]. It was observed upon comparing the XRD patterns of the mixture with the increased temperature that the peak intensities of mullite, tetragonal zirconia and monoclinic zirconia have increased due to decomposition at the peak intensity of zircon.

\subsubsection{XRD analyses of MZC45 composition}

Figure 2 shows the XRD patterns of MZC 45 mixture specimens sintered at 1450,1500 and $1550^{\circ} \mathrm{C}$ containing $45 \%$ solids by weight prepared from the mixture containing $7 \%$
Fig. 2 XRD patterns of MZC45 composition specimens sintered at 1450, 1500 and $1550^{\circ} \mathrm{C}$. M: mullite, $\mathrm{B}: \mathrm{m}-\mathrm{ZrO}_{2}$ $\mathrm{Z}_{\mathrm{t}}: \mathrm{t}-\mathrm{ZrO}_{2}, \mathrm{~T}$ : tridymite

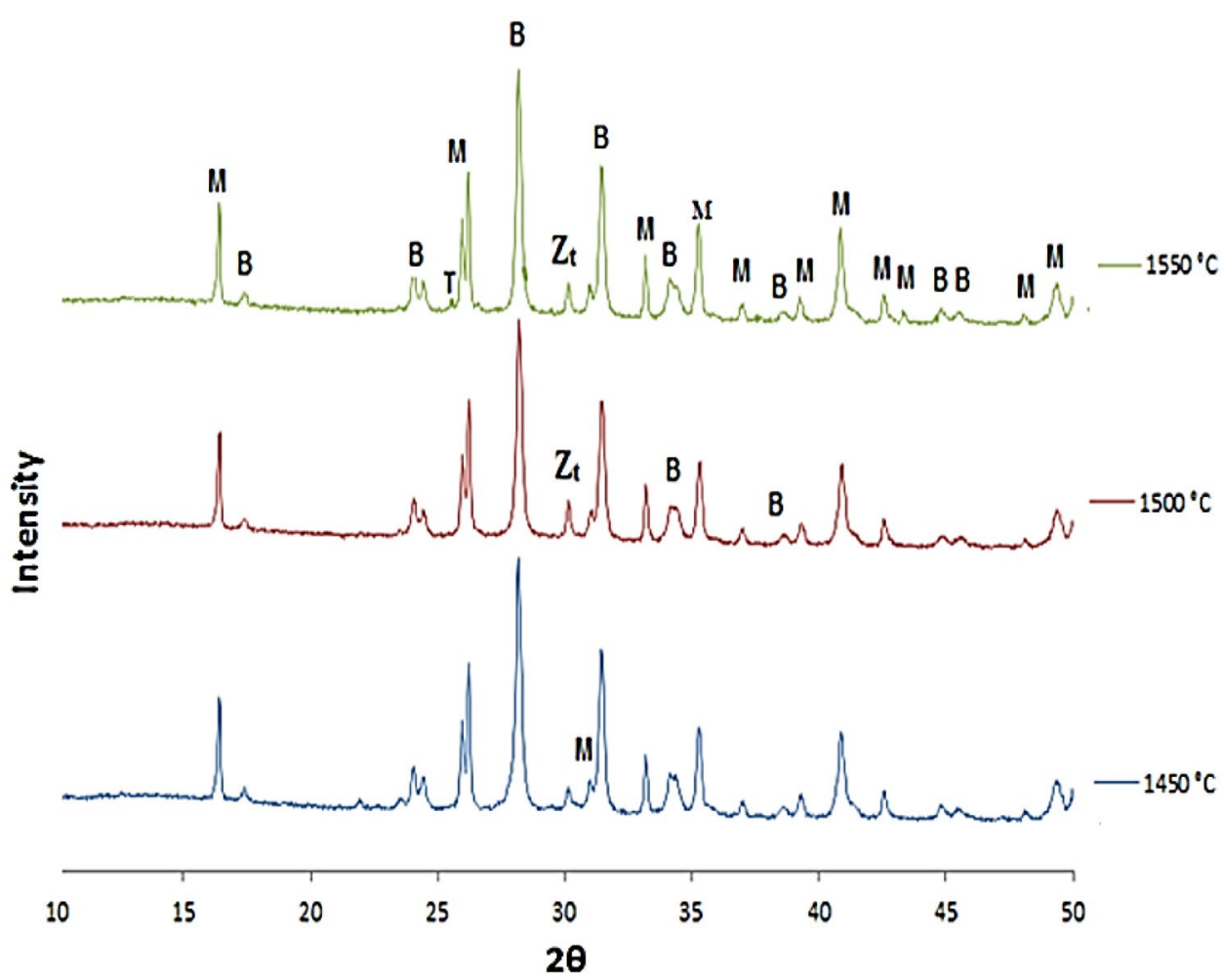


colemanite by weight. The most important and distinct difference between the mixtures coded as MZ045 and MZC45 which were obtained via slip casting is that the XRD patterns of the MZC45 mixture do not contain zircon, quartz and corundum-phase peaks. The colemanite additive caused zircon to decompose at low temperatures.

Moreover, intense peaks of monoclinic zirconia in addition to the tetragonal zirconia peak were detected in the MZC45 mixture specimen sintered at $1450^{\circ} \mathrm{C}$. In addition, a small peak of tridymite $\left(\mathrm{SiO}_{2}\right)$ was observed at $1550{ }^{\circ} \mathrm{C}$. The tridymite peak was probably nucleated from the liquid phase with increased temperature and was incorporated into the mullite formation by way of a progressive reaction.

\subsubsection{XRD analyses of MZ050 composition}

Results of XRD analyses for MZ050 mixture specimens sintered at 1450,1500 and $1550{ }^{\circ} \mathrm{C}$ can be seen in Fig. 3 . Unlike composite products obtained from a mixture containing $45 \%$ solids by weight; zirconia, corundum, quartz, monoclinic zirconia and mullite phases, as well as the tetragonal zirconia phase, were found in the XRD pattern of MZ050 mixture specimens sintered at $1450^{\circ} \mathrm{C}$.

Grain size distribution is an important parameter for these suspensions in the slip casting method, acting mainly on the maximum solid concentration. Small grains must fit the pores between large ones in order to enhance packing density. It has been determined following a literature survey that experimental results have confirmed that bimodal or a continuous broad grain size distribution can be used to achieve a high particle packing efficiency [29, 30]. On this basis, due to both having to bimodal grain size distribution (Fig. 14) and increase in solid concentration, it is thought to be due to the fact that grains were packed much tighter in slip casting thereby leading to an increase in the solid concentration of the prepared mixture as well as faster reactions due to the subsequent sintering process.

Moreover, unlike the MZ045 composition, no zircon phase peaks were observed at $1550^{\circ} \mathrm{C}$ in the XRD pattern of the MZ050 composition. This indicates that the reactions were completed at $1500^{\circ} \mathrm{C}$ in a non-additive composition containing $50 \%$ solids by weight.

\subsubsection{XRD analyses of MZC50 composition}

Figure 4 shows the XRD patterns of at 1450, 1500 and $1550^{\circ} \mathrm{C}$ for the MZC50 mixture containing $50 \%$ solids by weight prepared from the composition containing $7 \%$ colemanite by weight. Similar to MZC45 coded mixture obtained via slip casting, XRD patterns of the MZC50 mixture contain no zircon, quartz and corundum-phase peaks in and besides, a small tridymite $\left(\mathrm{SiO}_{2}\right)$ peak is observed at $1550^{\circ} \mathrm{C}$.

\subsubsection{XRD analyses of MZ055 composition}

The results of XRD analyses taken from MZ055 mixture specimens sintered at 1450,1500 and $1550^{\circ} \mathrm{C}$ are shown in Fig. 5. It can be concluded upon examining the phases in XRD patterns of non-additive composition sintered at 1450,1500 and $1550^{\circ} \mathrm{C}$ with maximum solids concentration in our study that the reactions have to a large extent been completed at $1500^{\circ} \mathrm{C}$. This is due to the increase of mullite peaks, $\mathrm{m}-\mathrm{ZrO}_{2}$ and $\mathrm{t}-\mathrm{ZrO}_{2}$, observed in the XRD pattern of the prepared mixture at $1500^{\circ} \mathrm{C}$ as well as the
Fig. 3 XRD patterns of MZ050 composition specimens sintered at 1450,1500 and $1550^{\circ} \mathrm{C}$. M: mullite, $\mathrm{B}: \mathrm{m}-\mathrm{ZrO}_{2}$, $\mathrm{Z}_{\mathrm{t}}: \mathrm{t}-\mathrm{ZrO}_{2}, \mathrm{Z}: \mathrm{ZrSiO}_{4}, \mathrm{C}$ : corundum, Q: quartz
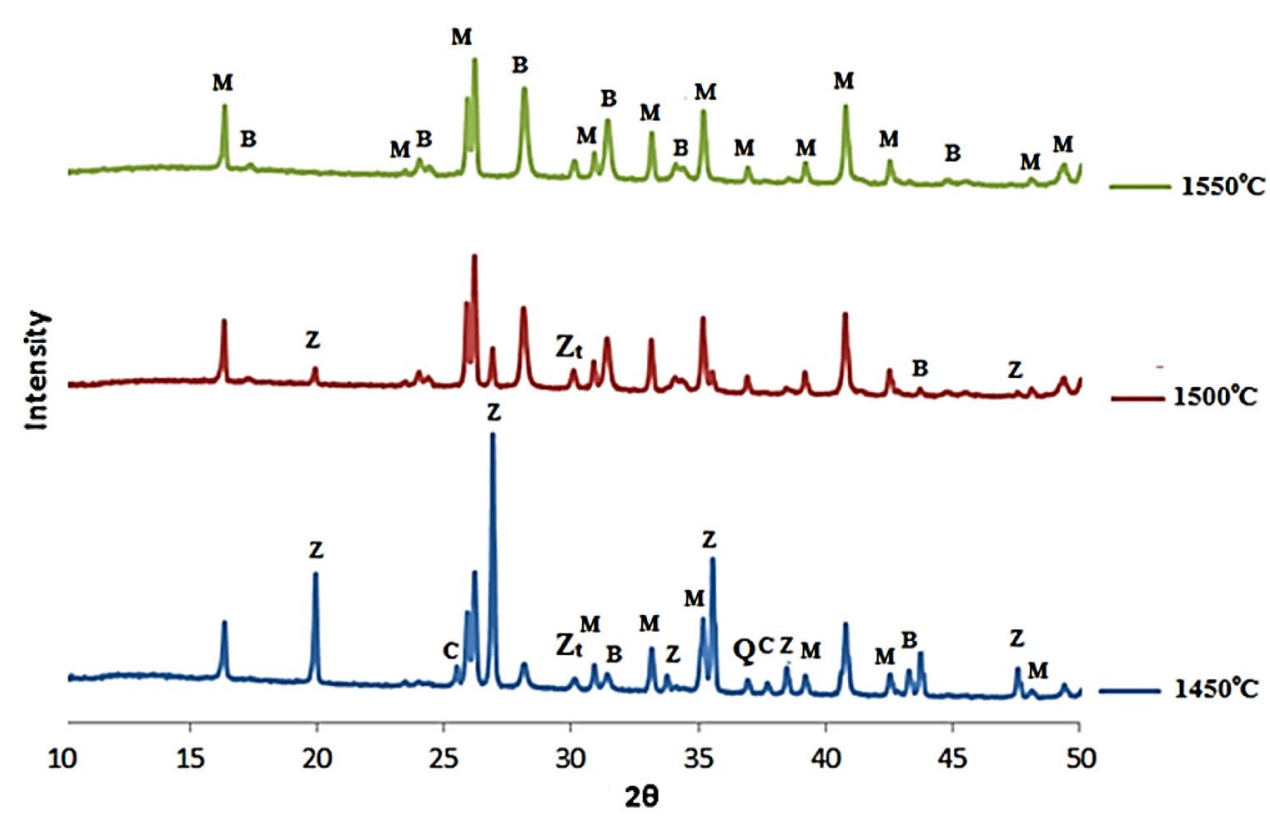

SN Applied Sciences 
Fig. 4 XRD patterns of MZC50 composition specimens sintered at 1450,1500 and $1550^{\circ} \mathrm{C}$. M: mullite, $\mathrm{B}: \mathrm{m}-\mathrm{ZrO}_{2}$; $\mathrm{Z}_{\mathrm{t}}: \mathrm{t}-\mathrm{ZrO}_{2}$, $\mathrm{T}$ : tridymite

Fig. 5 XRD patterns of MZ055 composition specimens sintered at 1450, 1500 and $1550^{\circ} \mathrm{C}$. M: mullite, $\mathrm{B}: \mathrm{m}-\mathrm{ZrO}_{2}$; $\mathrm{Z}: \mathrm{t}-\mathrm{ZrO}_{2}, \mathrm{Z}: \mathrm{ZrSiO}_{4}, \mathrm{C}:$ corundum, Q: quartz
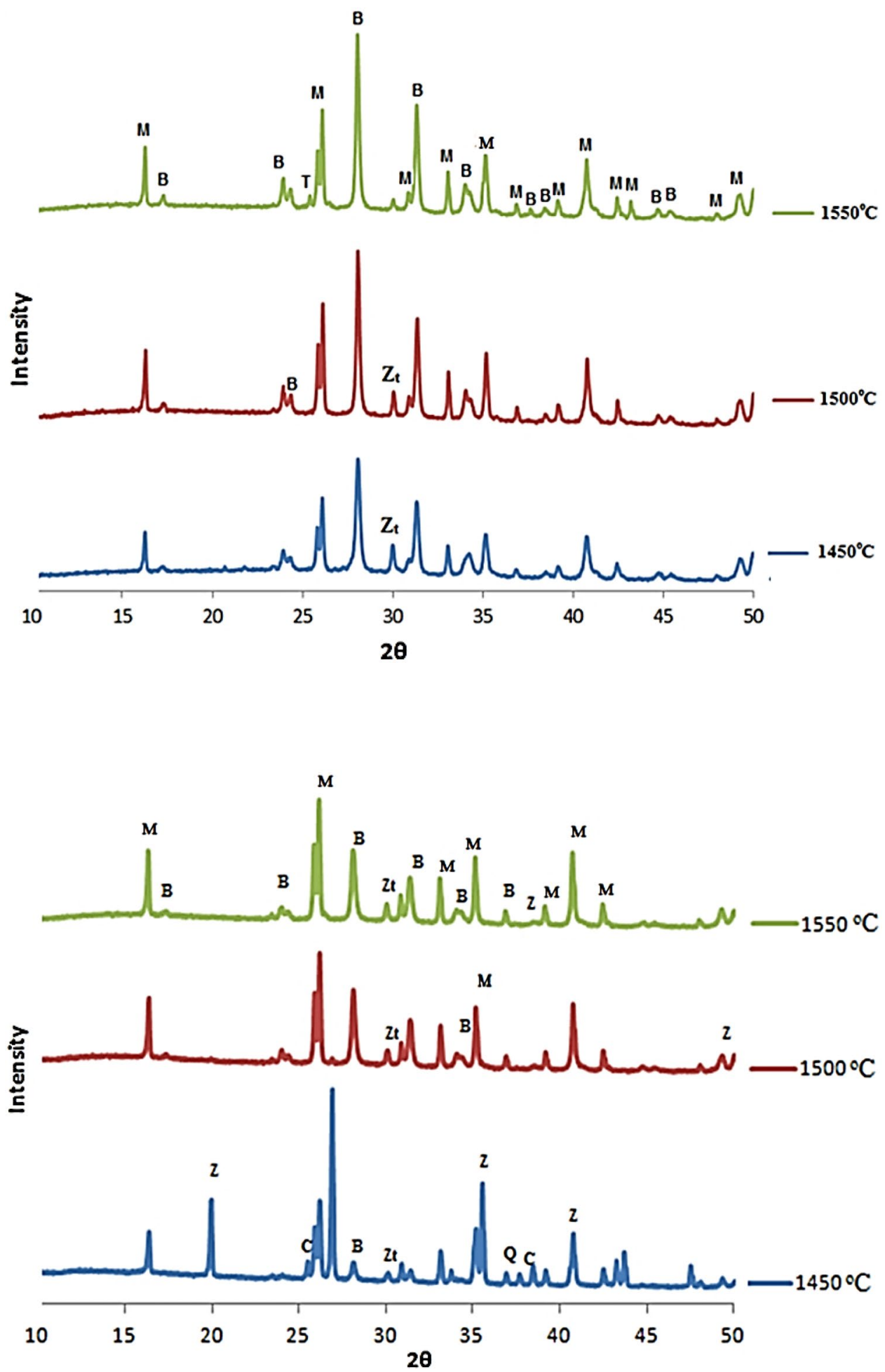

presence of a very small zirconia peak. Phase analyses results for non-additive compositions (MZ045, MZ050 and MZ055) show that the decomposition temperature of zircon decreases with increasing solids concentration.

\subsubsection{XRD analyses of MZC55 composition}

Figure 6 shows the results for XRD analyses on MZC 55 mixture samples sintered at 1450,1500 and $1550{ }^{\circ} \mathrm{C}$ containing $55 \%$ solids by weight prepared from a 
Fig. 6 XRD patterns of MZC55 composition specimens sintered at 1450, 1500 and $1550^{\circ} \mathrm{C}$. M: mullite, $\mathrm{B}: \mathrm{m}-\mathrm{ZrO}_{2}$, $\mathrm{Z}_{\mathrm{t}} \mathrm{t} \mathrm{t}-\mathrm{ZrO}_{2}$, $\mathrm{T}$ : tridymite

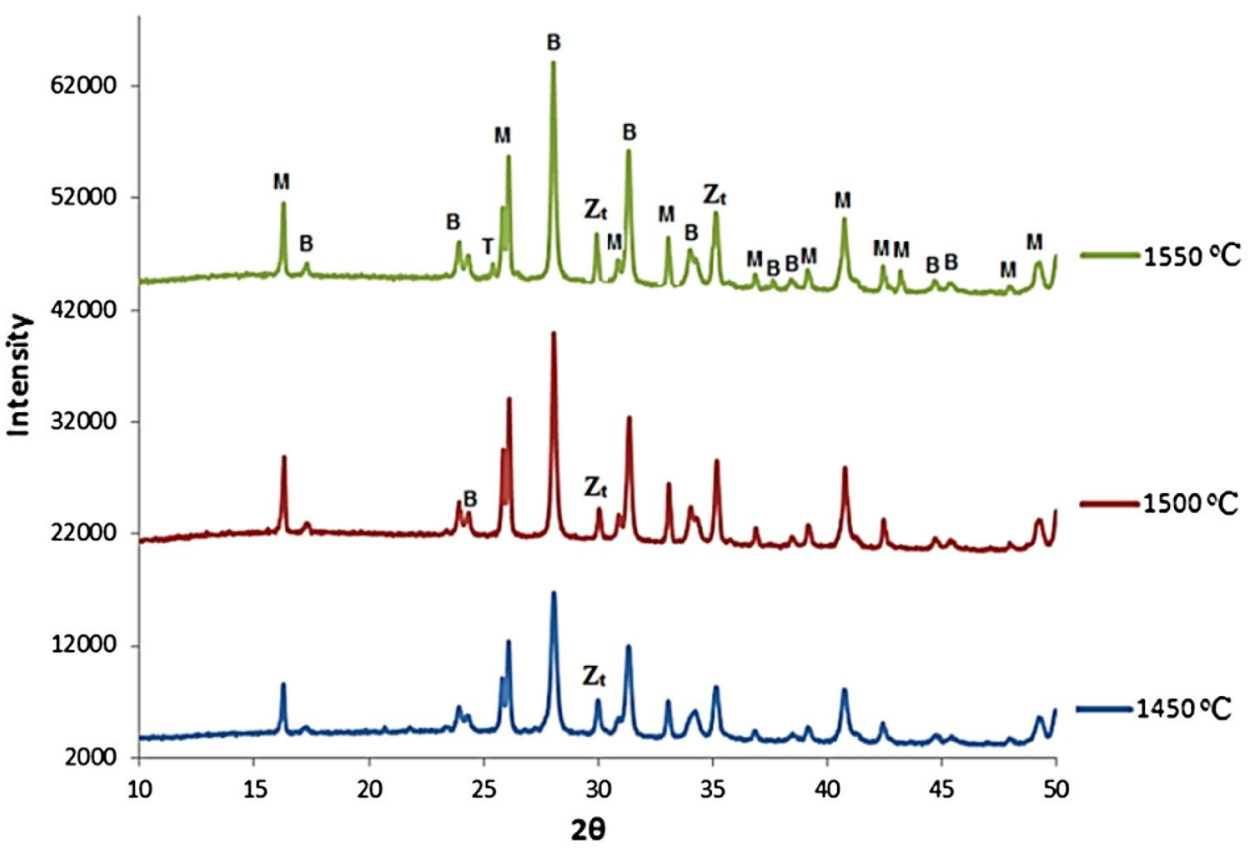

composition containing $7 \%$ colemanite by weight. While no zircon, quartz and corundum peaks were observed at all three temperatures with colemanite addition, a tetragonal zirconia $\left(\mathrm{t}-\mathrm{ZrO}_{2}\right)$ peak was observed at $1450^{\circ} \mathrm{C}$ when XRD patterns of the mixture coded MZC55 with colemanite obtained by slip casting is examined.

\subsection{Quantitative XRD analyses of composites obtained by slip casting}

Table 4 shows the quantitative XRD analysis results for non-additive (MZ045, MZ050, MZ055) and compositions containing colemanite (MZC45, MZC50, MZC55) produced by slip casting. Kaolinite, one of the starting raw materials,

Table 4 Quantitative XRD-Rietveld analysis results (wt\%) of non-additive (MZ045, MZ050, MZ055) and (MZC45, MZC50, MZC55) compositions containing colemanite

\begin{tabular}{|c|c|c|c|c|c|c|c|c|c|}
\hline Comp. & Temp. $\left({ }^{\circ} \mathrm{C}\right)$ & $\begin{array}{l}\text { Corundum } \\
\mathrm{Al}_{2} \mathrm{O}_{3}\end{array}$ & $\begin{array}{l}\text { Zircon } \\
\mathrm{ZrSiO}_{4}\end{array}$ & $\begin{array}{l}\text { Mullite } \\
3 \mathrm{Al}_{2} \mathrm{O}_{3} \cdot 2 \mathrm{SiO}_{2}\end{array}$ & $\begin{array}{l}\text { Zirconia } \\
\text { Total }\end{array}$ & $\begin{array}{l}\text { Zirconia } \\
\mathrm{m}-\mathrm{ZrO}_{2}\end{array}$ & $\begin{array}{l}\text { Zirconia } \\
\mathrm{t}-\mathrm{ZrO}_{2}\end{array}$ & $\begin{array}{l}\text { Cristobalite } \\
\mathrm{SiO}_{2}\end{array}$ & Tridymite \\
\hline \multirow[t]{3}{*}{ MZ045 } & 1450 & 15.2 & 25.8 & 53.4 & 4.8 & 4.5 & 0.3 & 0.8 & 0 \\
\hline & 1500 & 0 & 16.8 & 73.2 & 10 & 8.9 & 1.1 & 0 & 0 \\
\hline & 1550 & 0 & 9.5 & 73.8 & 16.7 & 15.2 & 1.5 & 0 & 0 \\
\hline \multirow[t]{3}{*}{ MZC45 } & 1450 & 0 & 0 & 58.2 & 39 & 36.8 & 2.2 & 2.7 & 0 \\
\hline & 1500 & 0 & 0 & 60.0 & 39 & 35.8 & 3.2 & 0 & 0 \\
\hline & 1550 & 0 & 0 & 60.0 & 39 & 35.7 & 3.3 & 0 & 1.2 \\
\hline \multirow[t]{3}{*}{ MZ050 } & 1450 & 13.7 & 19.2 & 59.3 & 7.8 & 6.4 & 1.4 & 0.1 & 0 \\
\hline & 1500 & 0 & 3.2 & 73.0 & 23.2 & 20.9 & 2.3 & 0.5 & 0 \\
\hline & 1550 & 0 & 0 & 73.1 & 26.8 & 24.5 & 2.3 & 0 & 0 \\
\hline \multirow[t]{3}{*}{ MZC50 } & 1450 & 0 & 0 & 60 & 36 & 33.7 & 2.3 & 2.7 & 1.3 \\
\hline & 1500 & 0 & 0 & 61.1 & 38.3 & 35.8 & 2.5 & 0 & 0 \\
\hline & 1550 & 0 & 0 & 62.0 & 38 & 34.0 & 4.0 & 0 & 0 \\
\hline \multirow[t]{3}{*}{ MZ055 } & 1450 & 12.4 & 18.7 & 58.7 & 9.3 & 7.9 & 1.4 & 0.9 & 0 \\
\hline & 1500 & 0 & 0.4 & 73.8 & 25.7 & 23.3 & 2.4 & 0.2 & 0 \\
\hline & 1550 & 0 & 0 & 74.1 & 25.9 & 23.5 & 2.4 & 0 & 0 \\
\hline \multirow[t]{3}{*}{ MZC55 } & 1450 & 0 & 1.6 & 54.6 & 42.7 & 39 & 3.7 & 1 & 0 \\
\hline & 1500 & 0 & 0 & 59.3 & 40 & 36.1 & 3.9 & 0.7 & 0 \\
\hline & 1550 & 0 & 0 & 59.4 & 40.2 & 36.1 & 4.1 & 0.3 & 0 \\
\hline
\end{tabular}


is transformed into mullite and amorphous silica during sintering. Similarly, zirconia and silica are formed when zircon is decomposed. The mullite phase is formed as a result of a reaction between alumina, which is one of the starting raw materials, and silica that forms as a result of decomposition. The values of $\mathrm{t}-\mathrm{ZrO}_{2} /$ total $\mathrm{ZrO}_{2}$ ratio are $0.06-0.18$ calculated from values of Table 3 , slightly changed for composites with and without colemanite. While the relative peak density of $\mathrm{t}-\mathrm{ZrO}_{2}$ increased with $\mathrm{CaO}$ from colemanite, there was a decrease in the peak density of $\mathrm{m}-\mathrm{ZrO}_{2}$ in MZC45, MZC50 and MZC55 mixtures depending on the increasing sintering temperature. This verifies that $\mathrm{CaO}$ stabilizes tetragonal zirconia at room temperature [22].

A significant amount of inert $\mathrm{Al}_{2} \mathrm{O}_{3}$ and $\mathrm{ZrSiO}_{4}$ is observed as a result of quantitative $\mathrm{XRD}$ analysis of composites produced from MZ045, MZ050 and MZ055 at $1450^{\circ} \mathrm{C}$. It is thought that the $\mathrm{Al}_{2} \mathrm{O}_{3}$ phase is incorporated into mullite formation with progressive reaction depending on the increasing sintering temperature; $\mathrm{ZrSiO}_{4}$ phase is also thought to be incorporated into monoclinic and tetragonal zirconia formation. In addition, the amount of non-reacting zircon is higher than that of (MZC45, MZC50 and MZC55) composites containing colemanite in (MZ045, MZ050 and MZ055) composites without colemanite additive. This is due to the fact that the increased post-forming wet density and packing of particles with increased solids concentration and the effect of colemanite addition on the reaction completion rate during sintering. The mixtures in which the decomposition is completed at $1450^{\circ} \mathrm{C}$ are those with colemanite $\left(\mathrm{Ca}_{2} \mathrm{~B}_{6} \mathrm{O}_{11} \cdot 5 \mathrm{H}_{2} \mathrm{O}\right)$. Colemanite contains more than $20 \%$ by weight of $\mathrm{CaO}$, and $\mathrm{CaO}$ is a basic oxide. The presence of basic oxides in silica fluids, and especially of coarse cations such as $\mathrm{CaO}$, increases the alkalinity ratio of the silica rich liquid. The fluidity and erosive properties of the liquids increase with the basicity ratio. The glassy phase, which decreases its viscosity due to both the increasing temperature and the basic oxide content, achieves the high erosive effect and the ability to decompose, thereby increasing the amount and kinetics of the zircon phase. Therefore, in the sintered samples of mixtures containing colemanite, the amount of zircon at $1450^{\circ} \mathrm{C}$ temperature is almost absent while the additivefree mixture contains a significant amount of zircon. In addition, $\mathrm{CaO}$ can accelerate mullite formation by lowering the glass viscosity [23]. Generally, zircon disassociates to yield $\mathrm{ZrO}_{2}$ and amorphous $\mathrm{SiO}_{2}$ on heating. The amorphous $\mathrm{SiO}_{2}$ softens with increasing temperature and starts to dissolve $\mathrm{Al}_{2} \mathrm{O}_{3}$ to form an amorphous aluminosilicate glass. Nucleation of mullite phase takes place after a critical alumina concentration is exceeded in the glass phase. Consequently, $\mathrm{Ca}$ and $\mathrm{B}$ with some impurities have reduced the decomposition temperatures of zircon, while increased the reaction capability of the amorphous silicate phase and the rate of completion of reactions $[22,26]$.

In addition, compositions for which zircon dissociation is completed at $1450{ }^{\circ} \mathrm{C}$ are the compositions containing colemanite $\left(\mathrm{Ca}_{2} \mathrm{~B}_{6} \mathrm{O}_{11} \cdot 5 \mathrm{H}_{2} \mathrm{O}\right)$ in composite products obtained via slip casting prepared with different solids concentrations. When a comparison was made, the expected compositions ( $w t \% 81$ mullite, wt $\% 19 \mathrm{ZrO}_{2}$ ) for MZO mixtures and ( $w t \% 72$ mullite, wt $\% 28 \mathrm{ZrO}_{2}$ ) for $\mathrm{MZC}$ mixtures were calculated by assuming the complete reaction. According to the Rietveld method, composition for MZ0 mixtures ( $73 \%$ by weight of mullite, $27 \%$ by weight of $\mathrm{ZrO}_{2}$ ) and for $\mathrm{MZC}$ mixtures $(60 \%$ by weight, $40 \%$ by weight of $\mathrm{ZrO}_{2}$ ) were found.

\subsection{Microstructure Analyses}

\subsubsection{Microstructure analyses of MZ045 compositions}

Microstructure images of MZ045 composition specimens sintered, respectively, at 1450,1500 and $1550{ }^{\circ} \mathrm{C}$ are given in Fig. 7. While a very high porosity was observed at $1450^{\circ} \mathrm{C}$ for the MZ045 specimen as can be seen in Fig. 7, it was observed that porosity decreased relatively with increasing temperature. This is in accordance with the increase in density and the decrease in firing shrinkage (Table 5) depending on the temperature of MZ045 composition. It has been observed that porosities grew in size due to mullite grains connecting to each other as a result of the impact of the glassy phase at $1550^{\circ} \mathrm{C}$.

\subsubsection{Microstructure analyses of MZC45 composition}

Microstructure images of MZC45 composition specimens sintered, respectively, at 1450,1500 and $1550^{\circ} \mathrm{C}$ are given in Fig. 8. The relative increase in the density draws attention when MZC45 specimens containing colemanite sintered at 1450,1500 and $1550{ }^{\circ} \mathrm{C}$ are compared with non-additive MZ045 specimen. This may be due to the effect of the liquid phase which is increased by the effect of colemanite addition with higher solids concentration. When microstructure images at 1500 and $1550{ }^{\circ} \mathrm{C}$ are examined, it can be observed that the $\mathrm{ZrO}_{2}$ phases are scattered in the fully interacting and randomly oriented mullite matrix. This is caused by a decrease in viscosity of the liquids formed due to colemanite addition. This liquid phase helps the phases formed to rearrange.

\subsubsection{Microstructure analyses of MZ050 composition}

Microstructure images of MZ050 composition specimens sintered, respectively, at 1450,1500 and $1550{ }^{\circ} \mathrm{C}$ are given in Fig. 9. It can be concluded as a result of 
Fig. 7 a Microstructure images of (MZ045) specimens sintered at a 1450, b 1500 and $\mathbf{c} 1550^{\circ} \mathrm{C}$ for $5 \mathrm{~h}$
Table 5 Firing shrinkage percentage, bulk density values in $\mathrm{g} / \mathrm{cm}^{3}$ and relative density values
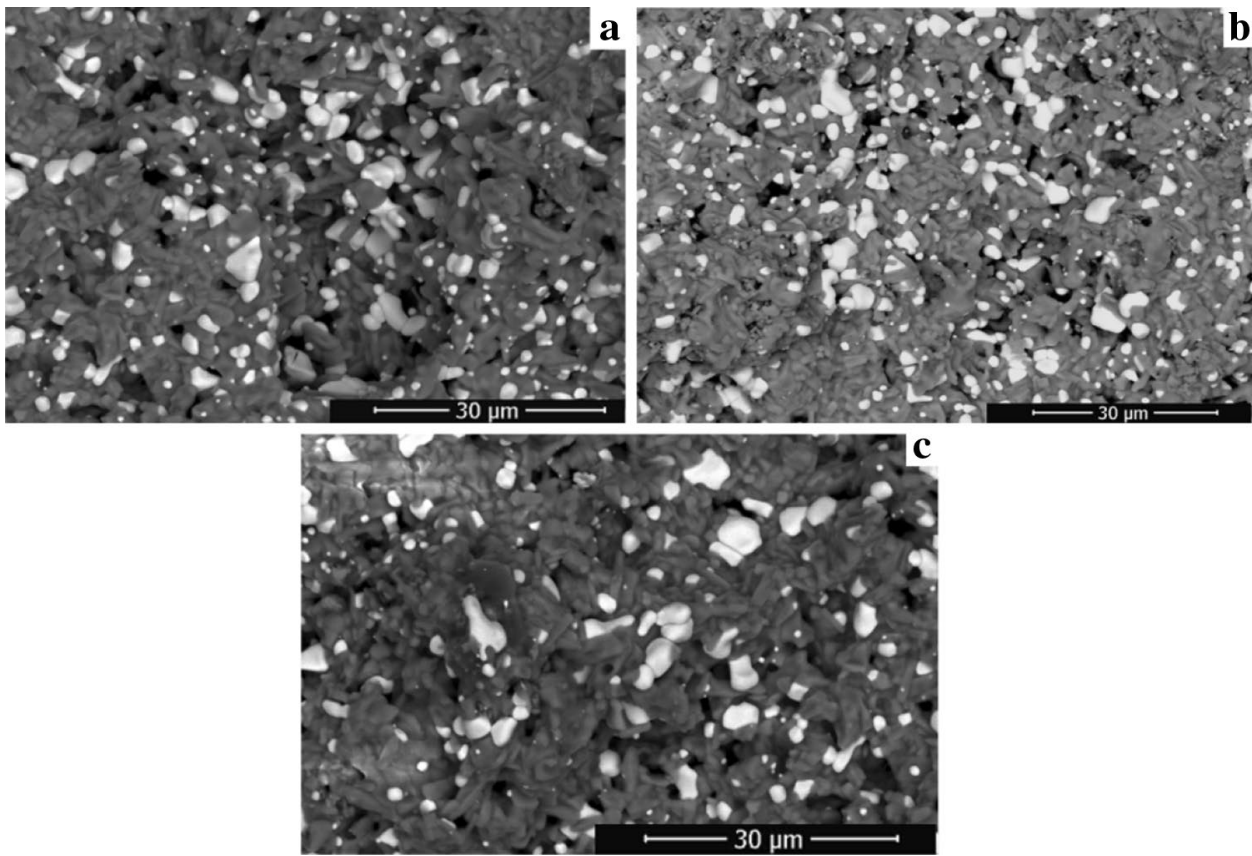

\begin{tabular}{lllllll}
\hline & MZ045 & MZC45 & MZ050 & MZC50 & MZ055 & MZC55 \\
\hline $1450{ }^{\circ} \mathrm{C}$ & & & & & & \\
Firing shrinkage (\%) & 15 & 26 & 16 & 28 & 17 & 30 \\
Bulk density $\left(\mathrm{g} / \mathrm{cm}^{3}\right)$ & 1.69 & 2.61 & 1.82 & 2.91 & 1.87 & 3.30 \\
Relative density (\%) & 47 & 67 & 50 & 75 & 52 & 85 \\
$1500^{\circ} \mathrm{C}$ & & & & & & \\
Firing shrinkage (\%) & 22 & 31 & 23 & 32 & 25 & 33 \\
Bulk density $\left(\mathrm{g} / \mathrm{cm}^{3}\right)$ & 2.29 & 3.18 & 2.60 & 3.28 & 2.70 & 3.37 \\
Relative density (\%) & 63 & 82 & 72 & 85 & 75 & 87 \\
$\begin{array}{l}1550{ }^{\circ} \mathrm{C} \\
\text { Firing shrinkage (\%) }\end{array}$ & 24 & 32 & 23 & 33 & 26 & 34 \\
Bulk density $\left(\mathrm{g} / \mathrm{cm}^{3}\right)$ & 2.47 & 3.25 & 2.60 & 3.37 & 3.01 & 3.49 \\
Relative density $(\%)$ & 68 & 84 & 72 & 87 & 83 & 90 \\
\hline
\end{tabular}

a comparison with microstructure images (Fig. 7) of MZ045 composition that while mullite crystals cannot be observed distinctly at all temperatures due to the increase in solids concentration and intergranular interaction in addition to the increase in density, crystals can be observed more distinctly at 1500 and $1550{ }^{\circ} \mathrm{C}$ in composite MZ050. The glassy phase is considered to have been observed at a lower rate when compared with microstructure image of MZ045 sintered at $1550{ }^{\circ} \mathrm{C}$ since the reactions are completed faster and more efficiently in the microstructure image for the MZ050 composition.

\subsubsection{Microstructure analyses of MZC50 composition}

Microstructure images of MZC50 composition specimens containing colemanite sintered, respectively, at 1450, 1500 and $1550^{\circ} \mathrm{C}$ are given in Fig. 10 . When compared with the microstructure (MZC45) composition containing 45\% solids by weight (Fig. 8), it can be observed that composites MZC50 are denser which also matches with the results of firing shrinkage and density tests. Another difference is that zirconia and mullite grains have been observed to be larger in specimens with higher solids concentration 
Fig. 8 a Microstructure images of (MZC45) specimens sintered at a $1450, \mathbf{b} 1500$ and $\mathbf{c} 1550^{\circ} \mathrm{C}$ for $5 \mathrm{~h}$
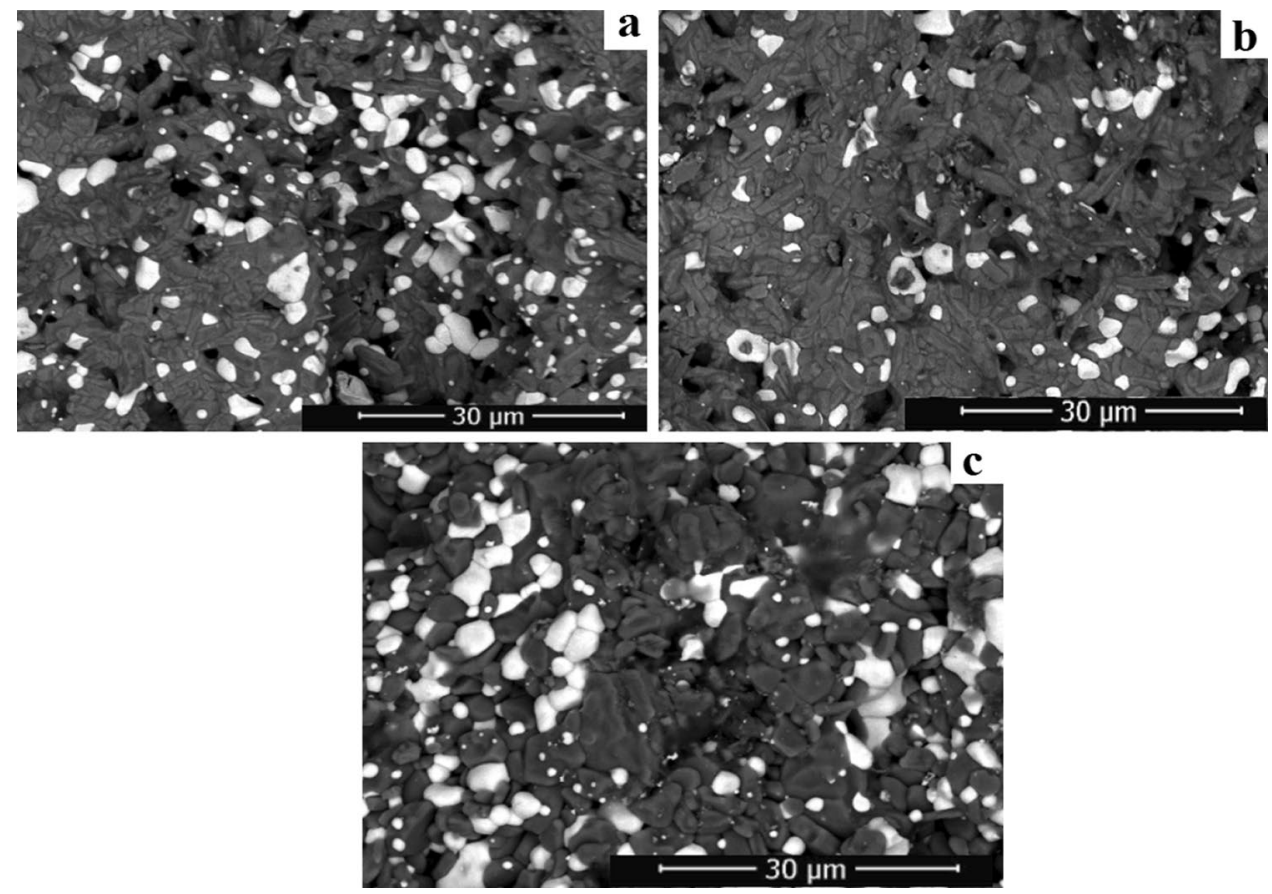

composition prepared from the same composition sintered at $1500^{\circ} \mathrm{C}$. This may be due to the effect of the liquid phase which is increased by the effect of colemanite addition with higher solids concentration. It is seen that mullite grains are connected to each other in the form of a dense matrix at $1550^{\circ} \mathrm{C}$. At the same time, two types of zirconia grains are present one of which is intergranular zirconia located between the mullite grains and the other one is intragranular zirconia present within mullite matrix. Many researchers $[19,31-33]$ put forth that spherical-shaped intragranular particles are tetragonal $\mathrm{ZrO}_{2}$, while the intergranular $\mathrm{ZrO}_{2}$ is mainly monoclinic.

\subsubsection{Microstructure analyses of MZ055 composition}

Microstructure images of MZ055 composition specimens sintered, respectively, at 1450,1500 and $1550^{\circ} \mathrm{C}$ are given in Fig. 11. When microstructure images of MZ055 composition are evaluated together with increased sintering temperature and solids concentration, it is possible to distinctly observe mullite crystals and intergranular
Fig. 9 a Microstructure images of (MZ050) specimens sintered at a $1450, \mathbf{b} 1500$ and $\mathbf{c} 1550^{\circ} \mathrm{C}$ for $5 \mathrm{~h}$
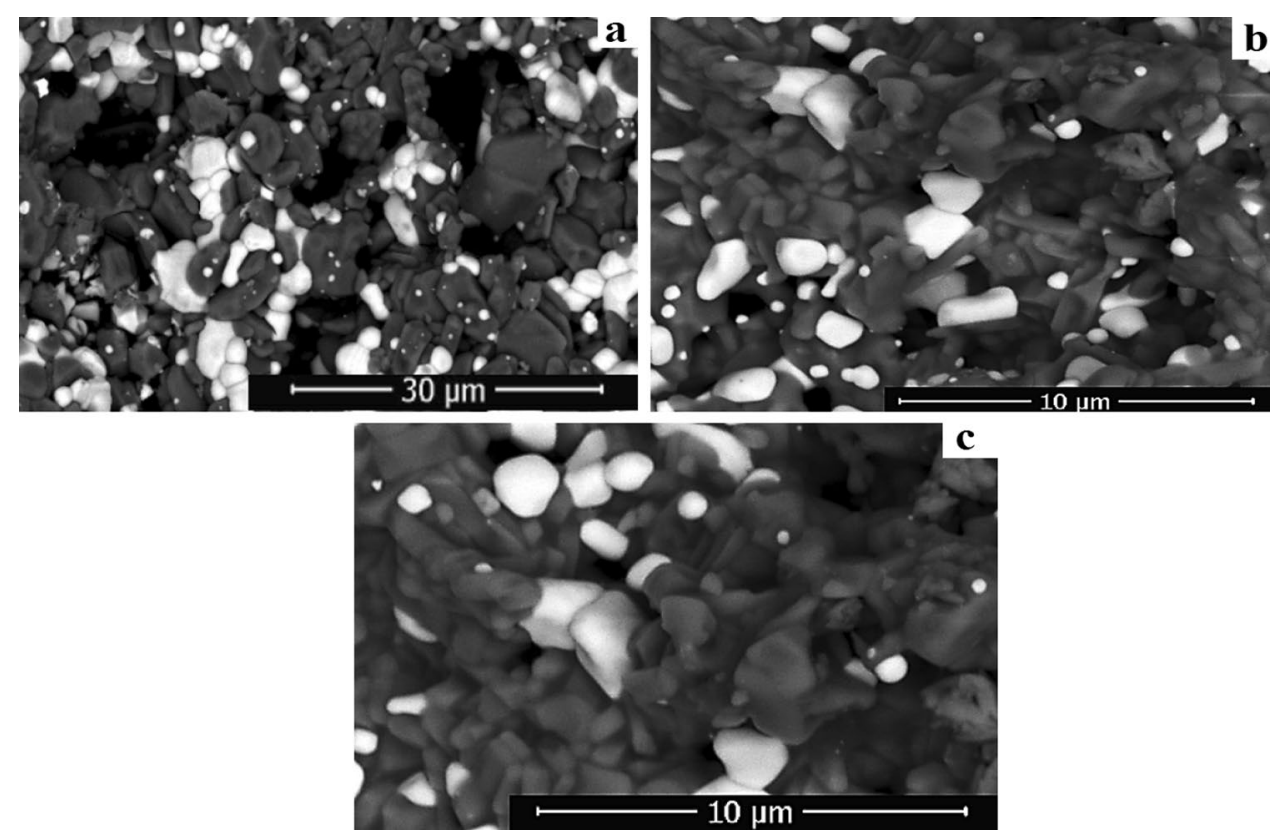
Fig. 10 Microstructure images of (MZC50) specimens sintered at a $1450, \mathbf{b} 1500$ and $\mathbf{c} 1550^{\circ} \mathrm{C}$ for $5 \mathrm{~h}$
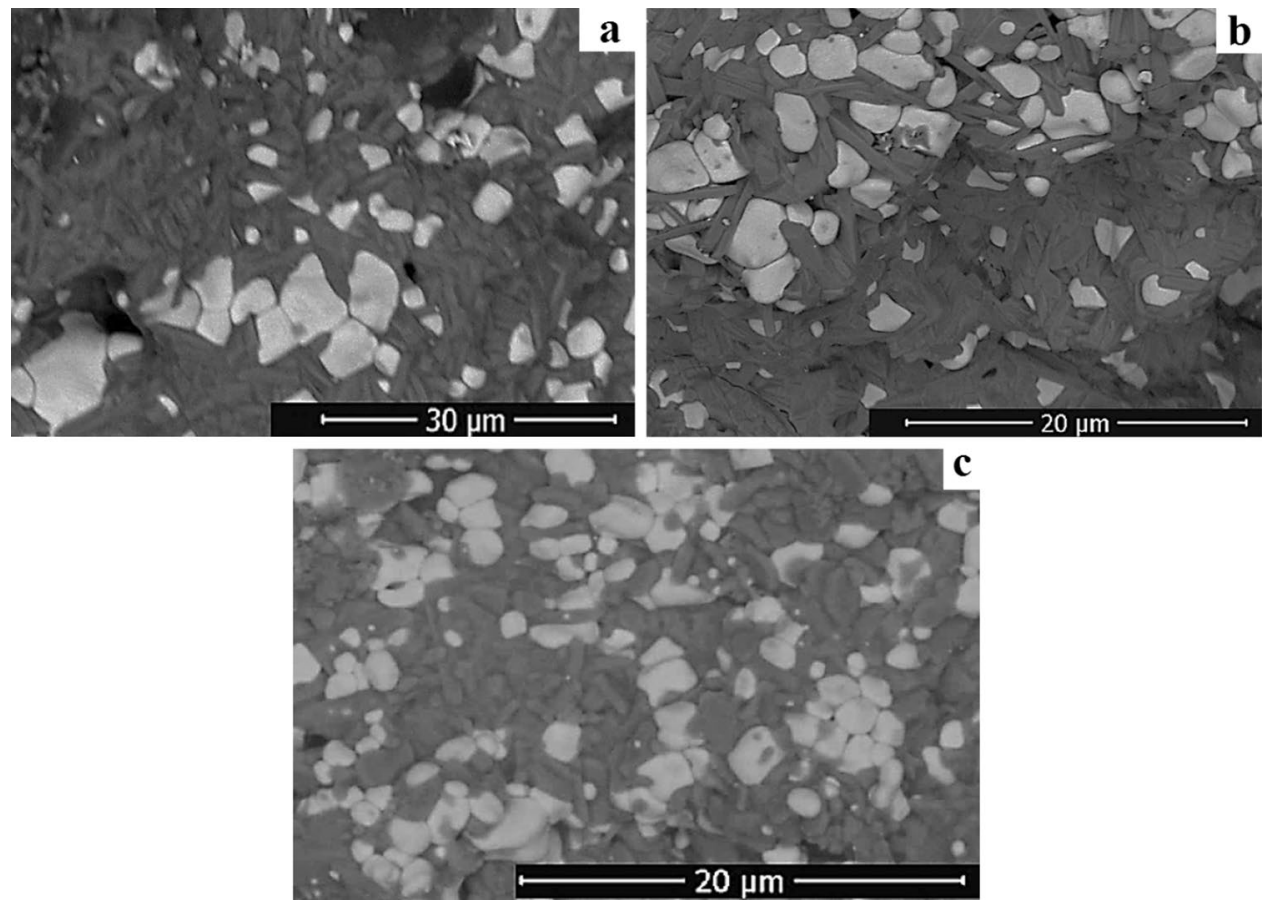

interaction at 1500 and $1550^{\circ} \mathrm{C}$. Zirconia (white grains) and mullite grains (gray grains) are observed to be much larger when MZ055 specimen sintered at $1550^{\circ} \mathrm{C}$ is compared with microstructure images of MZ045 and MZ050 composite specimens sintered at the same temperature.

\subsubsection{Microstructure analyses of MZC55 composition}

Microstructure images and energy-dispersive X-ray spectroscopy (EDX) analysis results of MZC55 composition specimens sintered, respectively, at 1450, 1500 and $1550^{\circ} \mathrm{C}$ are given in Figs. 12 and 13 . The white grains in
Fig. 11 Microstructure images of (MZ055) specimens sintered at a $1450, \mathbf{b} 1500$ and $\mathbf{c} 1550^{\circ} \mathrm{C}$ for $5 \mathrm{~h}$
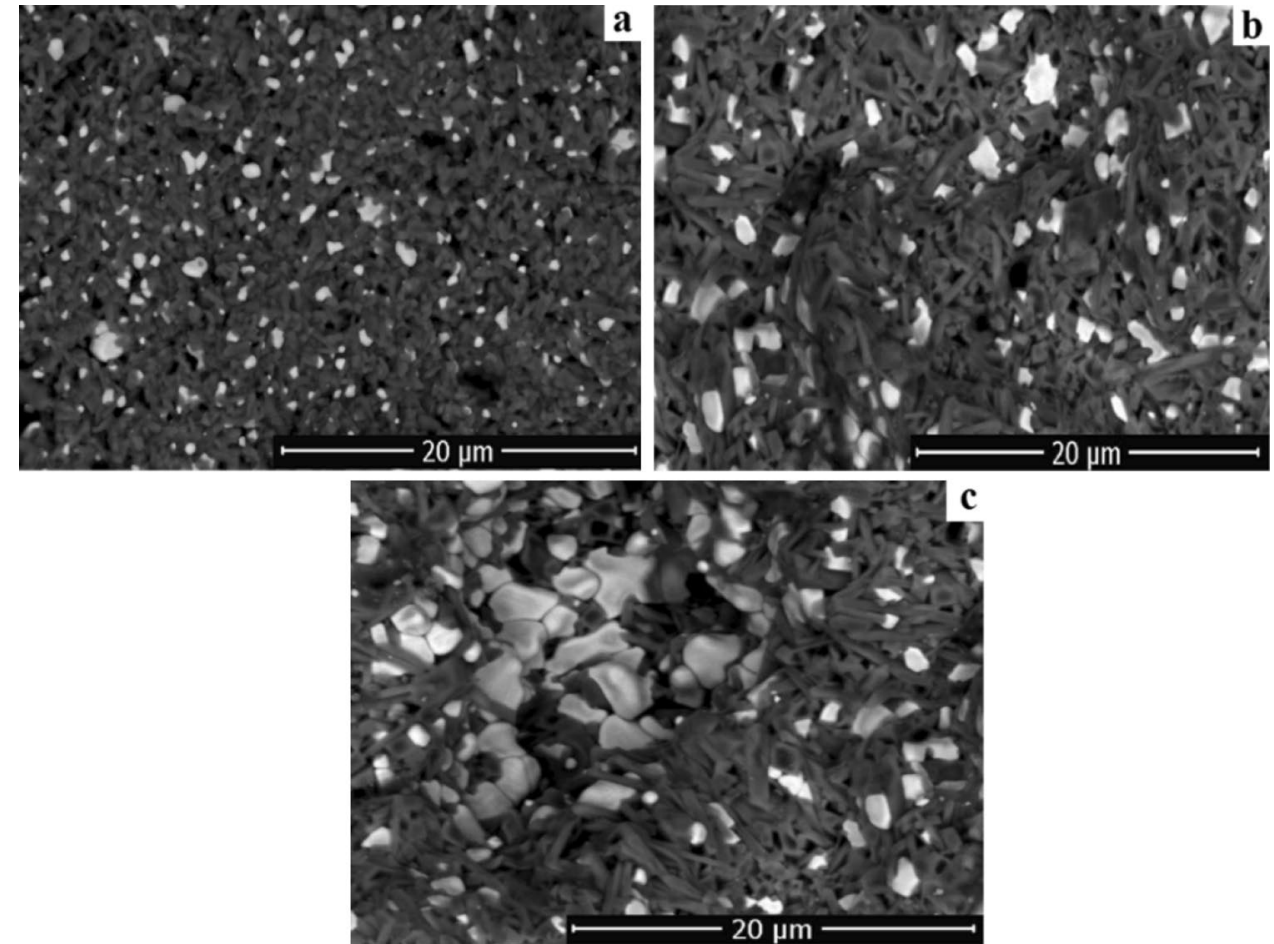

SN Applied Sciences a SPRINGER NATURE journal 
Fig. 12 Microstructure images of (MZC55) specimens sintered at a $1450, \mathbf{b} 1500$ and $\mathbf{c} 1550^{\circ} \mathrm{C}$ for $5 \mathrm{~h}$
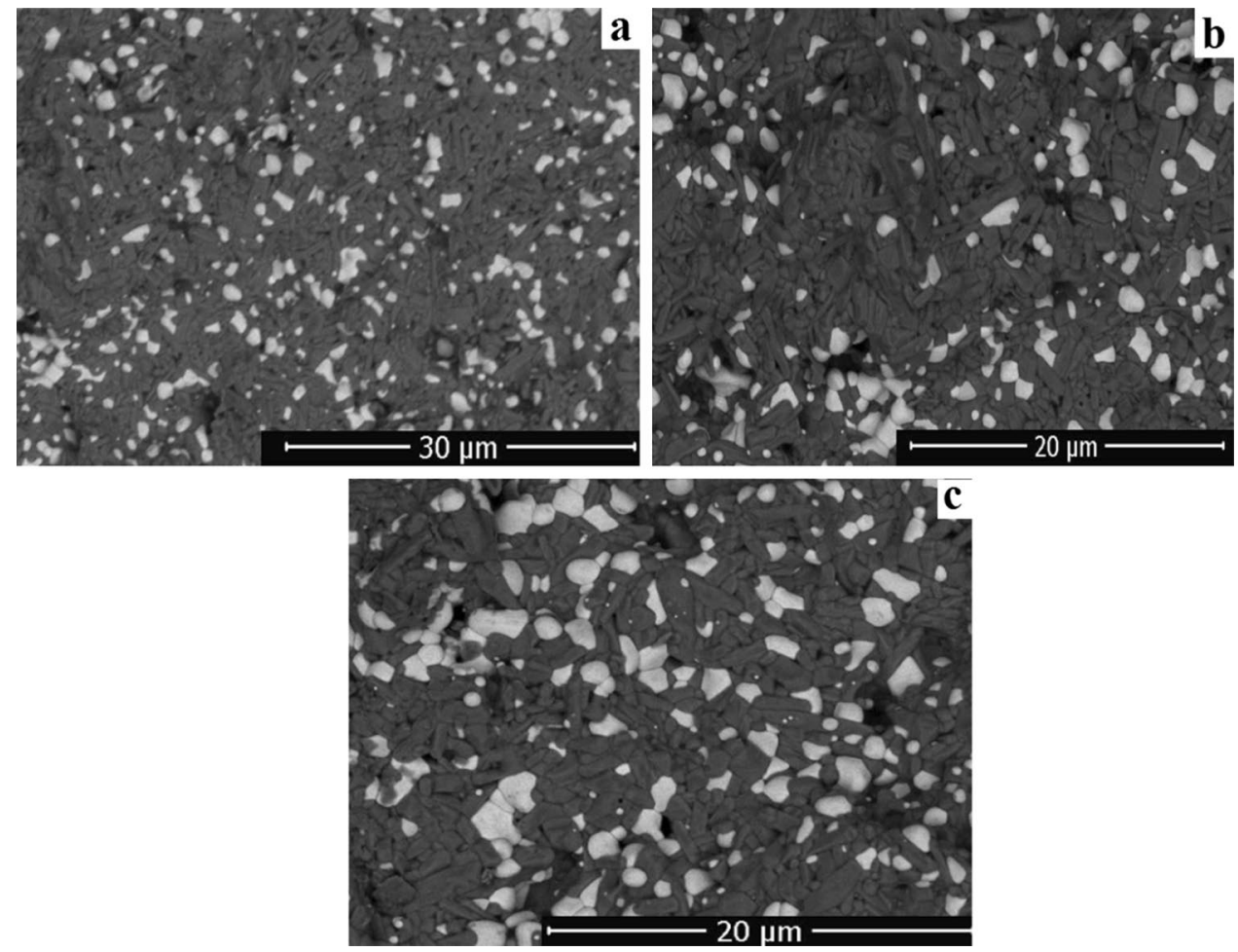

microstructure images are zirconia and the gray grains are mullite phases in energy-dispersive $\mathrm{X}$-ray spectroscopy (EDX) analysis results as given in Fig. 13. It can be observed when microstructure of MZC45 and MZC50 coded composites (Figs. 8, 10) are compared with microstructures of MZC55 coded composites are denser which also matches with the results of the firing shrinkage and density tests. Zirconia and mullite grains are larger in specimens sintered at $1550^{\circ} \mathrm{C}$, and the $\mathrm{ZrO}_{2}$ phases are scattered in fully interacting and randomly oriented mullite matrix which are in accordance with composition MZC50.

\subsection{Firing Shrinkage and Density}

The firing shrinkage and density values of MZ045, MZC45, MZ050, MZC45, MZ055 and MZC55 coded composite specimens sintered at 1450,1500 and $1550^{\circ} \mathrm{C}$ are given in Table 5. The relative densities of the composite materials can be calculated from the sum of the product of the density of each phase and the volume fraction. The mathematical expression [34] for the described method is as follows.

$\rho_{A B C \ldots}=\frac{\rho_{A} \rho_{B} \rho_{C} \ldots}{\rho_{A} \rho_{B} f_{C}+\rho_{A} \rho_{C} f_{B}+\rho_{C} \rho_{B} f_{A}+\cdots}$

where $\rho_{\text {Comp. }}$ is the density of composite, $f_{A}, f_{B}$ and $f_{C}$ are the volumetric percent division of the phases $A, B$ and $C_{i} \rho_{A}, \rho_{B}$ and $\rho_{C}$ are the density of the phases $A, B$ and $C$, respectively. When the equality is adapted to the mullite/ zirconia composite, the phases $A, B$ and $C$ can be considered as mullite, monoclinic zirconia and tetragonal zirconia, respectively. In terms of pure phases, density of the mullite, tetragonal zirconia and $\mathrm{m}-\mathrm{ZrO}_{2}$ is upon receipt $3.16,6.1$ and $5.83 \mathrm{~g} / \mathrm{cm}^{3}$, respectively. In this study, it can be considered that the relative density will vary between 3.61 and $3.87 \mathrm{~g} / \mathrm{cm}^{3}$ when both monoclinic and tetragonal phases of zirconia are present for most monoclinic mullite-zirconia composites synthesized. As can be seen from the firing shrinkage rate table and density values in composites obtained via slip casting, the highest value has been obtained as 3.49 while the lowest was $1.69 \mathrm{~g} / \mathrm{cm}^{3}$ in our study. Accordingly, shrinkage percentage and density values increase with increasing solids concentration and sintering temperature in all specimens obtained via slip casting. The highest density value was achieved with (MZC55) composition containing colemanite sintered at $1550^{\circ} \mathrm{C}$.

\section{Conclusions}

The mullite-zirconia composites containing $7 \mathrm{wt} \%$ colemanite additive were prepared by reaction sintering of alumina, kaolinite and zircon powder. In addition, the slip casting method was employed for producing these composites. Afterward, the physical properties, phase composition and microstructure of these composites after firing at $1450-1550{ }^{\circ} \mathrm{C}$ were evaluated. 

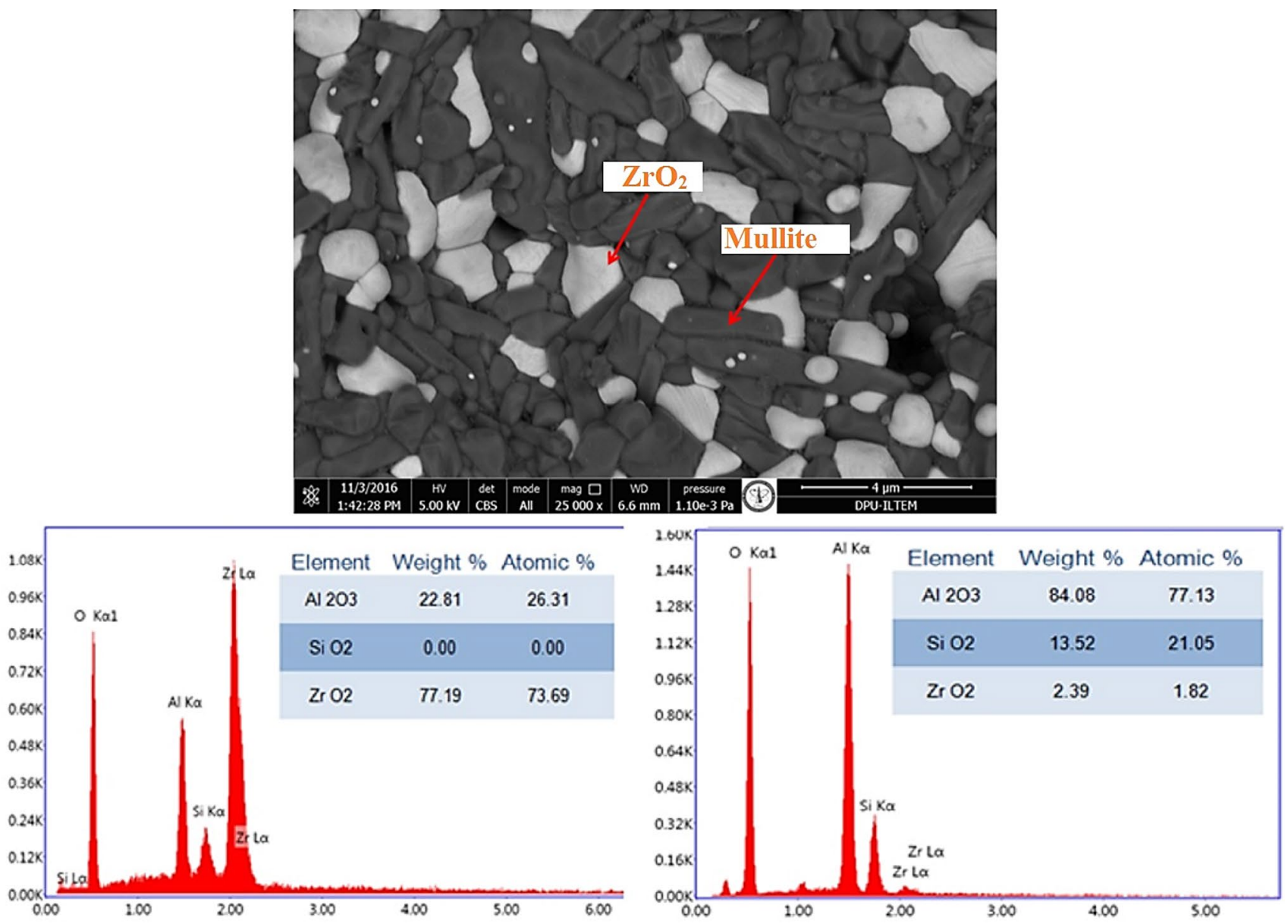

Fig. 13 EDX analysis of mixed (MZC55) composition

While there are no zircon peaks at almost all sintering temperatures for colemanite containing mixtures (MZC45, MZC50 and MZC55), zircon peaks can still be observed at the highest sintering temperature for additive-free mixtures (MZ045, MZ050 and MZ055) excluding the samples of MZ050 and MZ055 mixtures sintered at $1550{ }^{\circ} \mathrm{C}$. A bit more tetragonal zirconia phases in all specimens of (MZC45, MZC50 and MZC55) mixtures containing colemanite sintered at 1450,1500 and $1550^{\circ} \mathrm{C}$ are observed as a result of both qualitative and quantitative XRD analyses in comparison with the specimens of non-additive (MZ045, MZ050 and MZ055) mixtures sintered at the same temperatures. It is possible to conclude from XRD analysis that colemanite additive significantly reduced the decomposition temperature of zircon.

Another case is that conversion of the tetragonal (and cubic) zirconia phase, which is stable at high temperature depends on the grain size of zirconia. It is put forth in many sources that if tetragonal zirconia converted into monoclinic phase at room temperature if it is larger than a pure and certain (critical) dimension [13, 29, 35].
As can be seen in Figs. 1, 2, 3, 4, 5, 6 and Table 4, the fact that monoclinic zirconia phase is dominant in XRD analyses results from the facts that fragmentation product tetragonal zirconia grains are large in size and/or impurities such as $\mathrm{CaO}, \mathrm{MgO}, \mathrm{B}_{2} \mathrm{O}_{3}, \mathrm{Al}_{2} \mathrm{O}_{3}, \mathrm{Na}_{2} \mathrm{O}$ are probably dissolved in the mullite structure rather than the zirconia structure. The amount of impurities dissolved in tetragonal phase is very low which is not sufficient to make all the zirconia in the composite structure stable in the tetragonal phase [13].

As can be seen from the firing shrinkage percentage and bulk density values given in the findings section (Table 5), the highest and lowest density values are 3.49 and $1.69 \mathrm{~g} / \mathrm{cm}^{3}$, respectively. The grain size distribution (GSD) is an important parameter for these concentrated mixtures, acting mainly on the maximum solid volume fraction. To enhance particle packing, small particles must fit the interstices between large ones. Similar to the study carried out by Garrido et al. [30, 31] in our study experimental results have confirmed that bimodal or a continuous broad particle size distribution can be used to achieve 
$d(0,1): 0,104 \mu \mathrm{m}$

$d(0,5): 1,758 \mu \mathrm{m}$

$d(0,9): 22,574 \mu \mathrm{m}$

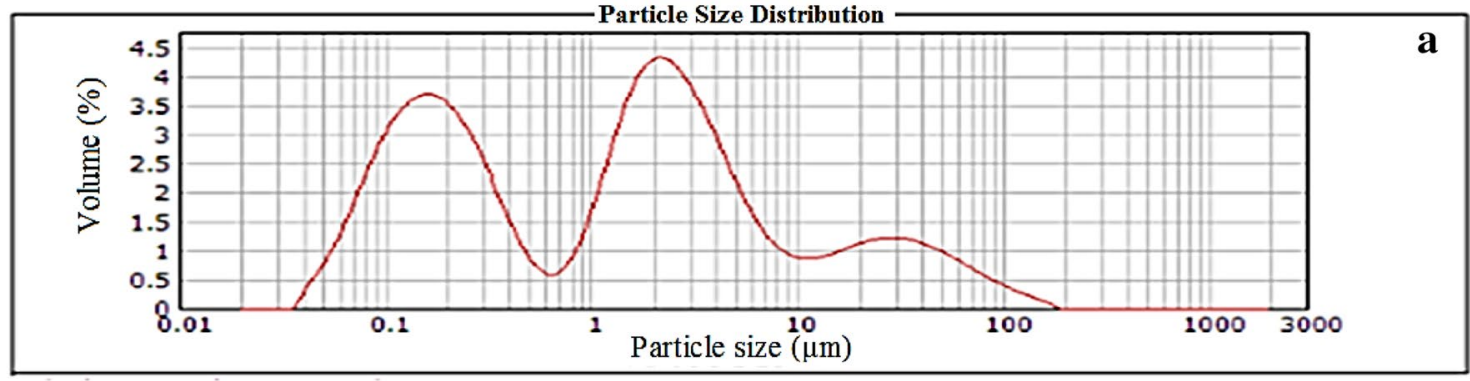

$\mathrm{d}(0,1): 0,104 \mu \mathrm{m}$

$d(0,5): 1,519 \mu \mathrm{m}$

$\mathrm{d}(0,9): 22,574 \mu \mathrm{m}$

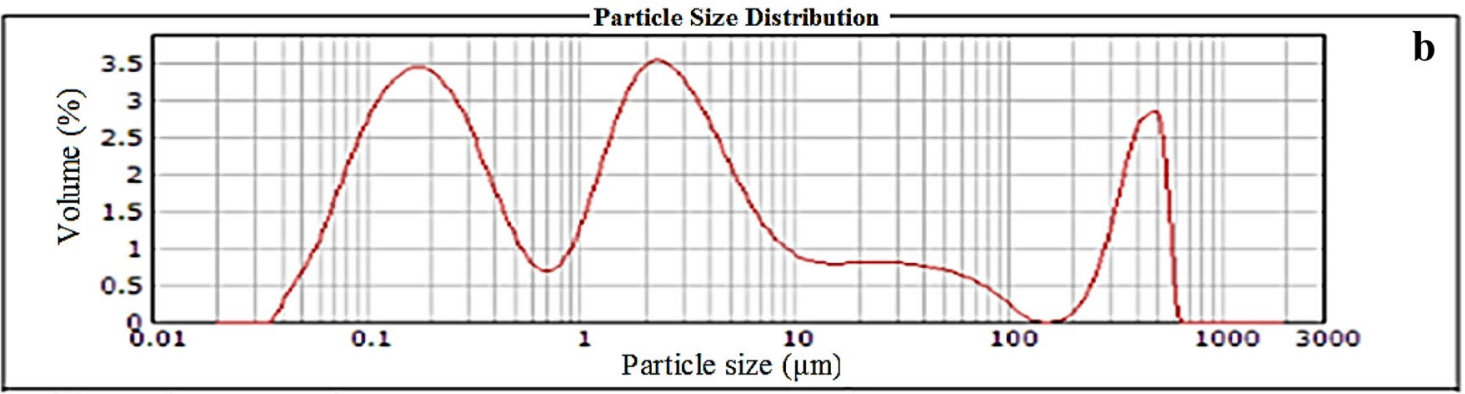

Fig. 14 Grain size distribution graphs of non-additive (a) and composition containing colemanite (b)

a high particle packing efficiency and to minimize the viscosity (Fig. 14).

There are no zircon peaks excluding those for the highest sintering temperature $\left(1550^{\circ} \mathrm{C}\right)$ of non-additive (MZ045, MZ050 and MZ055) mixtures and the MZ050 and MZ055 mixture specimens sintered at $1550^{\circ} \mathrm{C}$. The temporary liquid phases formed brought mullite and zirconia grains closer to each other during the reaction sintering of (MZC45, MZC50 and MZC55) specimens containing colemanite, as can be seen in SEM images of specimens (Figs. 8, 10, 12).

While MZ045, MZ050 and MZ055 have a very high porosity at $1450{ }^{\circ} \mathrm{C}$, the porosity decreases with increasing temperature; it can be said that MZC45, MZC50 and MZC55 specimens containing colemanite exhibit a denser and homogeneous microstructure at all temperatures due to the effect of both temperature and colemanite additive.

Microstructure images show that zirconia grains are larger than others and that some of them are very small, while some are medium-sized. Mullite grains (intergranular) are the large and medium-sized grains. It can be stated that intergranular zirconia grains are monoclinic due to their large size. There are very small zirconia grains in mullite grains (in the form of sedimentation products, and intragranular). It can be put forth that they are in the tetragonal phase as a result of (1) the size of these very small grains, (2) the environmental stress of the mullite crystals and (3) impurity ion contents such as $\mathrm{Si}^{+4}, \mathrm{Ca}^{+2}, \mathrm{Na}^{+}[13,36]$.

$\mathrm{CaO}$ in colemanite $\left(\mathrm{CaB}_{3} \mathrm{O}_{4}(\mathrm{OH})_{3} \cdot \mathrm{H}_{2} \mathrm{O}\right)$ has a significant impact on the stabilization of tetragonal zirconia $\left(\mathrm{t}-\mathrm{ZrO}_{2}\right)$ in the mullite matrix. Changes such as a volumetric growth of $\sim 4 \%$ and shear stress of $0.16(\sim 7 \%)$ take place during the polymorphic conversion from $\mathrm{t}-\mathrm{ZrO}_{2}$ to monoclinic zirconia $\left(\mathrm{m}-\mathrm{ZrO}_{2}\right)$. Such reversible polymorphic transformations absorb the diffusion energy of the crack formed on the material. Therefore, zirconia ceramics doped with low amounts of additives makes the material the tetragonal phase of which is the subject of discussion important in terms of toughness [13,22].

Consequently, it can be said in accordance with the study carried out by Aydin in 2013 that colemanite is an effective additive for mullite-zirconia composites produced with different solids concentrations of slip cast zircon, kaolinite and alumina mixture with regard to a comparison of the bulk and theoretical density values as well as the phase and microstructure properties [13].

\section{Compliance with ethical standards}

Conflict of interest The authors declared that they have no conflict of interests to this work. 


\section{References}

1. Bodhak S, Bose S (2011) Densification study and mechanical properties of microwave-sintered mullite and mullite-zirconia composites. J Am Ceram Soc 94(1):32-41

2. Aksay IA, Daabs DM, Sarıkaya M (1991) Mullite for structural, electronic and optical applications. J Am Ceram Soc 74:2343-2358

3. Schneider H, Schreuer J, Hildmann B (2008) Structure and properties of mullite-a review. J Eur Ceram Soc 28:329-344

4. Wahsh MMS, Khattab RM, Awaad M (2012) Thermo-mechanical properties of mullite/zirconia reinforced alumina ceramic composites. Mater Des 41:31-36

5. Shackelford JF, Doremus RD (2008) Ceramic and glass materials. Springe, New York

6. The all-purpose construction material, https://www.ceramtec. com/ceramic-materials/zirconium-oxide/. Accessed 12 Oct 2018

7. Chen LB (2006) yttria-stabilized zirconia thermal barrier coatings-a review. Surf Rev Lett 13(05):535-544

8. Thakare V (2012) Progress in synthesis and applications of zirconia. Int J Eng Res Dev 5(1):25-28

9. Rendtorff NM, Garrido LB, Agiletti EF (2010) Zirconia toughening of mullite-zirconia-zircon composites obtained by direct sintering. Ceram Int 36:781-788

10. Badiee SH, Otroj S, Rahmani M (2012) The effect of nano-TiO addition on the properties of mullite-zirconia composites prepared by slip casting. Sci Sinter 44:341-354

11. Martin R, Vick M, Kelly M et al (2013) Powder injection molding of a mullite-zirconia composite. J Mater Res Technol 283:263-273

12. Tokataş G, (2018) Production and characterization of mullite-zirconia composites by slip casting method, (M.S.Thesis). Kütahya Dumlupınar University, Institute of Sciences, Department of Material Science and Engineering

13. Aydın H, (2013) Synthesis of mullite/zirconia composite materials doped with boron minerals, (Ph.D. Thesis). Kütahya Dumlupınar University, Institute of science, Department of Ceramic Engineering

14. León-Carried M, Gutierrez CA et al (2014) Rheological, structural and mechanical characterization of monolithic zircon-alumina bodies. Mater Sci Forum 793:151-158

15. Suoto PM, Menezes RR et al (2011) Effect of $\mathrm{Y}_{2} \mathrm{O}_{3}$ additive on conventional and microwave sintering of mullite. Ceram Int $37: 241-248$

16. Bhattacharjee S, Singh SK, Galgali RK (2000) Preparation of zirconia toughened mullite by thermal plasma. Mater Lett 43:77-80

17. Kumar P, Nath MA et al (2015) Synthesis and characterization of mullite-zirconia composites by reaction sintering of zircon flour and sillimanite beach sand. Bull Mater Sci 38(6):1539-1544

18. Withey E, Petorak C, Trice R, Dickinson G, Taylor T (2007) Design of $7 \mathrm{wt} \% \mathrm{Y}_{2} \mathrm{O}_{3}-\mathrm{ZrO}_{2} /$ mullite plasma-sprayed composite coatings for increased creep resistance. J Eur Ceram Soc 27:4675-4683
19. Carvalho RG, Oliveira FJ, Silva RF, Costa FM (2014) Mechanical behaviour of zirconia-mullite directionally solidified eutectics. Mater Des 61:211-216

20. Khmelev AV (2014) Production of a mullite zirconia ceramic by the plasma-spark method. Refract Ind Ceram 55:137-142

21. Garrido LB, Aglietti EF (2000) Pressure filtration and slip casting of mixed. J Eur Ceram Soc 21:2259-2266

22. Kumar P, Nath M, Ghosh A, Tripathi HS (2016) Thermo-mechanical properties of mullite-zirconia composites derived from reaction sintering of zircon and sillimanite beach sand: effect of $\mathrm{CaO}$. Trans Nonferrous Met Soc China 26:2397-2403

23. Chandra D (2015) Comparison of the Role of $\mathrm{MgO}$ and $\mathrm{CaO}$ Additives on the Microstructures of Reaction-Sintered ZirconiaMullite Composite Int. J Appl Ceram Technol 12(4):771-782

24. Pena P, Miranzo P, Moya JS, De Aza S (1985) Multicomponent toughened ceramic materials obtained by reaction sintering. J Mater Sci 20:2011-2022

25. Wu JM, Lin C (1991) Effect of $\mathrm{CeO}_{2}$ on reaction-sintered mullite - zirconia ceramics. J Mater Sci 26:4631-4636

26. Aydın H, Gören R (2016) Effect of colemanite on properties of traditional mullite zirconia composite Cogent. Engineering 3:1-10

27. Shin D-W, Yoon D-H, Kim C-J, Chung Y-C, Auh KH (1998) Effect of the granule properties and compaction pressure on the green and sintered densities of $\mathrm{Al}_{2} \mathrm{O}_{3} / 15 \mathrm{vol} \% \mathrm{ZrO}_{2}$. J Ceram Soc Jpn 106(4):363

28. Yates JD, Lombardo SJ (2001) Effect of solids loading and dispersant concentration on strain mismatch and deformation of slip-cast green bodies. J Am Ceram Soc 84(10):2274-2280

29. Rendtorff NM, Garrido LB, Aglietti EF (2009) Zirconia toughening of mullite-zirconia-zircon composites: properties and thermal shock resistance. Ceram Int 35:779-786

30. Garrido LB et al (2006) Hardness and fracture toughness of mullite-zirconia composites obtained by slip casting. Mater Sci Eng, A 419:290-296

31. Garrido LB, Aglietti EF (2001) Effect of rheological properties of zircon-alumina suspensions on density of green casts. Mat. Res. 4:279-284

32. Wen FuH, Hsueh-Chuan H, Yun-Fen P, Shih-Ching W (2010) Microstructure and mechanical properties of dental 3Y-TZP ceramics by using $\mathrm{CaO}-\mathrm{P}_{2} \mathrm{O}_{5}$ glass as additive. Ceram Int 37[4]:1169-1174

33. Ebadzadeh $\mathrm{T}$, Ghasemi $\mathrm{E}$ (2002) Effect of $\mathrm{TiO}_{2}$ addition on the stability of $\mathrm{t}-\mathrm{ZrO}_{2}$ in mullite- $\mathrm{ZrO}_{2}$ composites prepared from various starting materials. Ceram Int 28(4):447-450

34. Sharma SCJ (2003) Equation for the density of particle-reinforced metal matrix composites: a new approach. J Mater Eng Perform 12:324

35. Zhao $S$, Huang Wang $C$ (2003) Mullite formation from reaction sintering of $\mathrm{ZrSiO}_{4} / \mathrm{a}-\mathrm{Al}_{2} \mathrm{O}_{3}$ mixtures. Mater Lett 57:1716-1722

36. Yaroshenko V, Wilkinson DS (2001) Sintering and microstructure modification of mullite/zirconia composites derived from silicacoated alumina powders. J Am Ceram Soc 84(4):850-858 